\title{
Psychological Impact and Their Associated Factors of Covid-19 Pandemic among Nurses of a Metropolitan City of Central Nepal
}

\author{
Rama Kumari Lamichhane, 'Bijaya Dhakal,' Aasha Thapa,' Kalyan Sapkota' \\ 'Bharatpur Hospital Nursing College, Bharatpur, Chitwan, ²Department of Internal Medicine, Bharatpur Hospital, Bharatpur, Nepal.
}

\section{ABSTRACT}

\section{Introduction}

Covid-19 poses a great challenge to the global health system. The nurses worked in Covid ward and fever clinic act as gatekeepers to the health care system in the public health response to Covid-19 epidemic. The consequences of lockdown, quarantine of Covid-19 pandemic has not only caused physical sufferings but also affected the mental health of the nurses around the globe. This study aimed to assess psychological impact and associated factors of Covid 19 pandemic among nurses working in different level of hospital at Bharatpur Municipality Chitwan, Nepal.

\section{Methods}

A cross-sectional descriptive study was conducted among 150 nurses working in different hospitals of Bharatpur Municipality. Non-probability Purposive Sampling Technique was used and Data was collected via online survey using Google Form questionnaire. Covid-19 peritraumatic distress index (CPDI) questionnaire was used to find out psychological impact. Statistical analysis of data was done using SPSS version 20.

\section{Results}

Total of 150 nurses were involved in the study where $99.3 \%$ were female, $45.3 \%$ in the age group of $26-35$ years, mean age $27.22 \pm 6.612$ years, $87.2 \%$ bachelor in nursing. Mild to moderate peritraumatic distress was found in $47.33 \%$ and $16 \%$ of respondents found to have severe distress level. Chi-square test showed that respondents level of knowledge $(p=0.003)$ and presence of chronic disease $(p=0.007)$ was statistically significant with level of distress.

\section{Conclusions}

Majority of the nurses had some form of psychological distress. Study highlights the need for counseling for distress and mental health during Covid-19 pandemic. A focus on improving mental wellbeing of nurses should be immediately initiated.

Keywords: Covid-19; nurses; pandemic; peritraumatic distress.

\section{INTRODUCTION}

The coronavirus disease 2019 (Covid-19) is currently a threat to the global health in an unprecedented manner. Nepal, a South Asian country, is no exception and is affected by the outbreak with overwhelming effects on its economy and health system. ${ }^{1}$

The Covid-19 pandemic had a massive impact on health care systems, increasing the risks of psychological distress in frontline health professionals. $^{2}$ The increasing number of confirmed cases and deaths, overburden in work, inadequate personal protective equipment (PPE) supply, lack of specific treatment, vulnerability to infection and having to stay in quarantine, as well as feelings of being inadequately supported

Correspondence: Bijaya Dhakal, Bharatpur Hospital Nursing College, Bharatpur. Email: bijaya.ija2015@gmail.com, Phone:+977-9845176585. 
in the workplace and home, can contribute to the mental burden of health workers. ${ }^{3}$

Healthcare workers (HCWs) are vulnerable to developing trauma or stress-related disorders in addition to other mental health conditions during large-scale disease outbreaks. If not adequately addressed, these stress could lead to immediate and long-term psychological consequences. In general, HCWs have a higher risk of mental health problems - including a greater risk of suicide, suicidal ideation and selfharm behaviors - than the general population.

(4) During a pandemic, they are vulnerable to mental health problems because of the high risk of infection, increased work stress and fear of spreading the virus to their families. ${ }^{5}$

A timely assessment of mental health status and mental health needs of health workers will help to respond and reduce psychological distress earlier, improve their mental wellbeing and increase the work performance. ${ }^{6}$ Healthcare workers like nurses' are the primary group who come in contact with patients, an important source of exposure to infected cases in healthcare settings. Corona Virus Disease 2019 (Covid-19) pandemic has brought all the health care professionals including nurses to work as a frontline member, which may bring threat to mental wellbeing. ${ }^{6,7}$ However, evidence regarding the psychological impact and its associated factors of Covid 19 among nurses is not available in Nepal, in this context, this study aimed to evaluate psychological impact and its associated factors of Covid among nurses working in Bharatpur, Nepal.

\section{METHODOLOGY}

Descriptive cross-sectional survey was used to assess the psychological impact and its associated factors of Covid 19 pandemic among nurses working in different hospital of Bharatpur Municipality, Chitwan District. Non-probability Purposive Sampling Technique was used and Data were collected via online survey using Google Form questionnaire. Data were collected for one-month duration from June 1, 2020 to July 1, 2020. Ethical Clearance was taken from Institutional Review Committee (IRC) Bharatpur Hospital Chitwan. The instrument used for data collection consisted of two sections (i) Covid-19 peritraumatic distress index (CPDI) ${ }^{8}$ a validated tool (Cronbach's alpha 0.95) consisting of 24 items that includes anxiety, depression, specific phobias, cognitive changes, avoidance and compulsive behavior, physical symptoms and loss of social functioning. The total score for CPDI is 96 (normal: 0-24; mild to moderate PD: 25-48; severe PD: 49-96) and (ii) semi structure self-administered questionnaire developed by researcher to identify the associated factors. Data analysis done by using SPSS version 20. Descriptive statistics used to identify the level of psychological distress and inferential statistics (chi- square test) was done to find out associated factors.

\section{RESULTS}

Among 150 respondents 99.3\% were female, $45.3 \%$ were in the age group of 26-35 years, mean age was $27.22 \pm 6.612$ years, $87.2 \%$ had qualification of bachelor and above, 59.3\% married and $46.7 \%$ had worked in general ward, 38.7\% have got training on Covid 19 and $80 \%$ have more than 1-year work experience. The sociodemographic characteristics of the respondents is shown in table 1.

\begin{tabular}{|c|c|c|}
\hline Variables & Frequency & Percent \\
\hline \multicolumn{3}{|l|}{ Gender } \\
\hline Male & 1 & 0.7 \\
\hline Female & 149 & 99.3 \\
\hline \multicolumn{3}{|l|}{ Age in years } \\
\hline Less than \& equals to 25 & 67 & 44.7 \\
\hline More than 25 & 83 & 55.3 \\
\hline \multicolumn{3}{|l|}{ Level of Education } \\
\hline ANM \& PCL Nursing & 53 & 12.8 \\
\hline Bachelor \& above & 97 & 87.2 \\
\hline \multicolumn{3}{|l|}{ Marital status } \\
\hline Married & 89 & 59.3 \\
\hline Unmarried & 60 & 4.0 \\
\hline Widow & 1 & 0.7 \\
\hline
\end{tabular}


Lamichhane et al. Psychological Impact and their Associated Factors of Covid-19...

\begin{tabular}{|l|c|c|}
\hline Working department & & \\
Fever clinic or Covid ward & 12 & 8.0 \\
General ward & 70 & 46.7 \\
Emergency & 8 & 5.3 \\
Critical care unit & 60 & 40.0 \\
\hline Training on Covid 19 & 58 & \\
Yes & 92 & 61.3 \\
No & & \\
Working experience & 30 & 20 \\
Less than 1 year & 120 & 80 \\
\hline More than 1 year & & \\
\hline
\end{tabular}

About half (47.33\%) of the respondents experienced mild/moderate level of Covid Peritraumatic Distress whereas, $16 \%$ of the respondents reported severe level of peritraumatic distress.
Simple Bar Count of Total_CPDI_Categorized

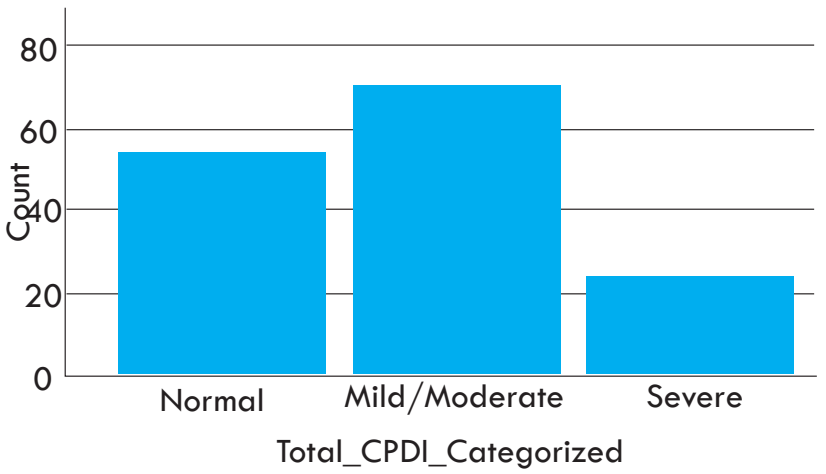

Figure 1. Level of peritraumatic distress (Psychological Impact) among Nurses $n=150$

\begin{tabular}{|c|c|c|c|c|c|c|}
\hline & \multirow{2}{*}{ Statements } & \multicolumn{5}{|c|}{ Percentage } \\
\hline & & 0 & 1 & 2 & 3 & 4 \\
\hline 1. & Compared to normal times, I felt more nervous and anxious. & 10 & 16.7 & 41.3 & 12.7 & 19.3 \\
\hline 2 & $\begin{array}{l}\text { I felt insecure and bought lot of masks, medications, sanitizers, gloves and } \\
\text { other home supplies. }\end{array}$ & 8 & 20.7 & 38 & 6.7 & 26.7 \\
\hline 3 & $\begin{array}{l}\text { I can't stop myself from imagining myself and my family being infected and } \\
\text { feel terrified and anxious about it. }\end{array}$ & 10.7 & 14.7 & 34 & 11.3 & 29.3 \\
\hline 4 & I feel empty and helpless no matter what I do? & 32.7 & 14.7 & 34 & 8 & 10.7 \\
\hline 5 & $\begin{array}{l}\text { I feel sympathetic to the Covid-19 patient and their families. I feel sad about } \\
\text { them }\end{array}$ & 6 & 5.3 & 17.3 & 18.7 & 52 \\
\hline 6 & $\begin{array}{l}\text { I feel helpless and angry about people around me, such as the governors } \\
\text { and media? }\end{array}$ & 14 & 13.3 & 33.3 & 18 & 21.3 \\
\hline 7 & I am losing faith in the people around me & 30.7 & 16 & 34.7 & 12 & 6.7 \\
\hline 8 & $\begin{array}{l}\text { I collect information about Covid-19 all day. Even it's not necessary I can't } \\
\text { stop myself. }\end{array}$ & 17.3 & 15.3 & 23.3 & 17.3 & 26.7 \\
\hline 9 & $\begin{array}{l}\text { I will believe the Covid-19 information from all the sources without any } \\
\text { evaluation. }\end{array}$ & 46 & 14.7 & 22 & 8.7 & 8.7 \\
\hline 10 & $\begin{array}{l}\text { I would rather believe in negative news about Covid-19 and be skeptical } \\
\text { about the good news. }\end{array}$ & 42.7 & 15.3 & 23.3 & 8 & 10.7 \\
\hline 11 & I am constantly sharing news about Covid 19 (mostly negative) & 48 & 14.7 & 23.3 & 4.7 & 9.3 \\
\hline 12 & I feel empty and helpless no matter what I do? & 32.7 & 14.7 & 34 & 8 & 10.7 \\
\hline 13 & I feel more irritable and have frequent conflict with my family. & 45.33 & 16 & 27.3 & 7.3 & 4.1 \\
\hline 14 & I feel tired and sometimes even exhausted. & 18 & 23.3 & 36.7 & 11.3 & 10.7 \\
\hline 15 & Due to feelings of anxiety, my reaction are becoming sluggish. & 36.7 & 25.3 & 24.7 & 6.7 & 6.7 \\
\hline 16 & I find it hard to concentrate. & 31.3 & 20 & 31.3 & 127 & 4.7 \\
\hline 17 & I find it hard to make any decisions. & 32.7 & 19.3 & 34 & 7.3 & 6.7 \\
\hline 18 & $\begin{array}{l}\text { During this Covid-19 outbreak, I often fee dizzy, have back pain or chest } \\
\text { discomfort. }\end{array}$ & 55.3 & 18.7 & 17.3 & 4 & 4.7 \\
\hline 19 & I feel uncomfortable when communicating with others. & 50 & 14 & 18.7 & 9.3 & 8 \\
\hline 20 & Recently I rarely talk to my family. & 56.7 & 9.3 & 21.3 & 6 & 6.7 \\
\hline 21 & $\begin{array}{l}\text { I cannot sleep well. I always dream about myself or my family being infected } \\
\text { by corona virus. }\end{array}$ & 57.3 & 16.7 & 16.7 & 5.3 & 4 \\
\hline 22 & I lost my appetite. & 60.7 & 14.7 & 18.7 & 5.3 & .7 \\
\hline 23 & I have constipation or frequent urination & 64 & 17.3 & 11.3 & 4 & 3.3 \\
\hline 24 & $\begin{array}{l}\text { During this Covid-19 outbreak, I often feel stomach pain, bloating or other } \\
\text { stomach discomforts. }\end{array}$ & 63.3 & 14.7 & 14 & 4 & 4 \\
\hline
\end{tabular}




\begin{tabular}{|c|c|c|}
\hline Factors & & $\begin{array}{c}p \\
\text { Value }\end{array}$ \\
\hline $\begin{array}{l}\text { Age } \\
\text { Less than } 25 \\
\text { More than } 25\end{array}$ & 1.201 & 0.549 \\
\hline $\begin{array}{l}\text { Working ward } \\
\text { Fever and Covid Ward } \\
\text { Other than fever and Covid ward }\end{array}$ & 3.247 & 0.777 \\
\hline $\begin{array}{l}\text { Training received on Covid } 19 . \\
\text { Yes } \\
\text { No }\end{array}$ & 3.575 & 0.167 \\
\hline $\begin{array}{l}\text { Types of family } \\
\text { Nuclear } \\
\text { Joint and Extended }\end{array}$ & 1.201 & 0.549 \\
\hline $\begin{array}{l}\text { Having chronic illness } \\
\text { Yes } \\
\text { No }\end{array}$ & 9.802 & 0.007 \\
\hline $\begin{array}{l}\text { Level of Education } \\
\text { ANM \& PCL } \\
\text { Bachelor \& Above }\end{array}$ & 6.787 & 0.003 \\
\hline
\end{tabular}

Table shows that Covid 19 peritraumatic distress level was statistically significant with respondent's level of Education and Presence of Chronic disease.

\section{DISCUSSION}

Covid-19 pandemic pose a great burden on health care systems worldwide leading to great psychological pressure on nurses treating the patients. Evidences have showed the rise in psychological problems including stress, anxiety, depression, posttraumatic stress disorder worldwide among the health care workers. ${ }^{9-11}$

In this study about half $(47.33 \%)$ of the respondents experienced mild/moderate level of Covid Peritraumatic Distress whereas, $16 \%$ of the respondents reported severe level of peritraumatic distress. However, study conducted by Neupane MS et al, had 37.6\% of nurses with high level of stress and $54.7 \%$ of nurses had moderate level of stress. ${ }^{7}$ In similar studies done in Brazil where mild to moderate level of peritraumatic distress was found among 52.9\% (N=654). ${ }^{12}$ Similar type of studies done on Nepalese community people revealed that Mild to moderate peritraumatic distress was found among $17.82 \%$ and Covid-19 Peritraumatic Distress index score was 14.67 (SD \pm 9.09) which was contrast to present study. ${ }^{13}$ A study conducted among nursing staffs in Taiwan had normal scores in nearly two-thirds (61.8\%) and only $3.4 \%$ had scores indicating severe distress. ${ }^{14}$

This study shows that Covid 19 peritraumatic distress level was statistically significant with respondent's level of Education $(p=0.003)$ and Presence of Chronic disease $(p=0.007)$ as factors affecting psychological impact among nurses. A study conducted by Khanal P et al showed that Stigma faced by health workers and history of medication for mental health was significantly associated with experiencing symptoms of anxiety and inadequate precautionary measures in the workplace was significantly associated with higher odds of exhibiting symptoms of anxiety. ${ }^{6}$

The study has some limitations that could make generalization of the findings difficult. First, this study was conducted during the early phase of pandemic, thus the mental health outcomes might still reflect conditions existing before the pandemic, and second there might have been the introduction of selection bias, because the questionnaires were distributed non-randomly via online survey using google forms.

\section{CONCLUSIONS}

Majority of nurses working as frontline health workers had significant distress level on Covid 
Peritraumatic Psychological Distress scale. This has immediate and long term consequences in their health and job performance. A focus on improving mental wellbeing of nurses should be immediately initiated to protect their wellbeing and improve work performance and strengthen health system.

\section{ACKNOWLEDGEMENTS}

Authors of this study would like to express their sincere thanks to all the participants of the study, without their cooperation, this study would not have been successful.

Conflict of Interest: None

Financial Disclosure: None

\section{REFERENCES}

References

1. Shrestha R, Shrestha S, Khanal P, Kc B. Nepal's first case of Covid-19 and public health response. Journal of travel medicine. 2020;27(3).

2. Giusti EM, Pedroli E, D'Aniello GE, Stramba Badiale C, Pietrabissa G, Manna $\mathrm{C}$, et al. The Psychological Impact of the Covid-19 Outbreak on Health Professionals: A Cross-Sectional Study. Front Psychol. 2020;11:1684.

3. Neto MLR, Almeida HG, Esmeraldo JDa, Nobre CB, Pinheiro WR, de Oliveira $\mathrm{CRT}$, et al. When health professionals look death in the eye: the mental health of professionals who deal daily with the 2019 coronavirus outbreak. Psychiatry Research. 2020:112972.

4. Dutheil F, Aubert C, Pereira B, Dambrun M, Moustafa F, Mermillod $\mathrm{M}$, et al. Suicide among physicians and health-care workers: A systematic review and meta-analysis. PloS one. 2019;14(12):e0226361.

5. Xiang Y-T, Yang Y, Li W, Zhang L, Zhang Q, Cheung T, et al. Timely mental health care for the 2019 novel coronavirus outbreak is urgently needed. The Lancet Psychiatry. 2020;7(3):228-9.
6. Khanal P, Devkota N, Dahal M, Paudel $\mathrm{K}$, Joshi D. Mental health impacts among health workers during Covid-19 in a low resource setting: a cross-sectional survey from Nepal. Globalization and health. 2020;16(1):1-12.

7. Neupane MS, Angadi S, Joshi A, Neupane HC. Stress and anxiety among nurses working in tertiary care hospitals in Nepal during Covid-19 pandemic. Journal of Chitwan Medical College. 2020;10(3).

8. Qiu J, Shen B, Zhao M, Wang Z, Xie B, Xu $Y$. A nationwide survey of psychological distress among Chinese people in the Covid-19 epidemic: implications and policy recommendations. General psychiatry. 2020;33(2).

9. Shen X, Zou X, Zhong X, Yan J, Li L. Psychological stress of ICU nurses in the time of Covid-19. Springer; 2020.

10. Tan BYQ, Chew NWS, Lee GKH, Jing M, Goh Y, Yeo LLL, et al. Psychological Impact of the Covid-19 Pandemic on Health Care Workers in Singapore. Ann Intern Med. 2020;173(4):317-20.

11. Bettinsoli ML, Di Riso D, Napier JL, Moretti L, Bettinsoli P, Delmedico $\mathrm{M}$, et al. Mental Health Conditions 
of Italian Healthcare Professionals during the Covid-19 Disease Outbreak. Appl Psychol Health Well Being. 2020;12(4):1054-73.

needs among residents of a community housing during Covid-19. Journal of Patan Academy of Health Sciences. 2020;7(2):14-22.

12. von Krakauer Hubner C, Bruscatto ML, Lima RD. Distress among Brazilian university students due to the Covid-19 pandemic: survey results and reflections. medRxiv. 2020.

13. Samson $P$, Shah JN. Peritraumatic distress and perceived mental healthcare

14. Feng MC, Wu HC, Lin HT, Lei L, Chao $\mathrm{CL}, \mathrm{Lu} \mathrm{CM}$, et al. [Exploring the Stress, Psychological Distress, and Stressrelief Strategies of Taiwan Nursing Staffs Facing the Global Outbreak of Covid-19]. Hu Li Za Zhi. 2020;67(3):6474.

Citation: Lamichhane R, Dhakal B, Thapa A, Sapkota K. Psychological Impact and their Associated Factors of Covid-19 Pandemic among Nurses of a Metropolitan City of Central Nepal. JCMS Nepal. 2021; 17(2); $159-64$. 